\title{
IbM-JOINT BUSINESS GROUP"PASTRIES BEPANG OR RENCINA AND OTHER TRADITIONAL CAKES"
}

\author{
Johny Manaroinsong ${ }^{1,}$ Mareyke Greety Velma Sumual ${ }^{2}$ \\ 1 Faculty of Economics, Manado State University \\ email: manaroinsongjohny@gmail.com, johnm@unima.ac.id \\ 2 Faculty of Economics, Manado State University \\ email:mareykesumual@gmail.com
}

\begin{abstract}
The joint group of pastries "Bepang or Rencina and other Traditional Cakes" is a business group that is home industry. The main problem of this business is that the product is still large, so it is not interesting to see or to eat it. In addition there is no packing system or packaging that meets the standards of quality marketing, so the product quickly damaged. Other things labeling products have not written down the name of the product, without any expiration date, product composition, product superiority, name making and so on. Another problem faced is the marketing of its products. Previously traded transactions can only be done by face-to-face, while it opens the opportunity to sell over the phone, and even now is very easy and often done via the Internet, such as in facebook account, twitter and others for promotion. Implementation of IbM program is implemented as an effort to empower the KUBE group in the field of entrepreneurship and product marketing through training activities that focuses on business development and marketing. Methods of program implementation that will be conducted are: (1) business management training, (2) Business marketing training, (3) and (4) assistance. All of these methods are a unity of this IbM program. The strategic target audience in this activity is the community of Joint Business Group belonging to the form of business of bepang pastry (rencina) and other wet cakes located in Karondoran Village, East Langowan District, Minahasa Regency. The number of trainees is 20 people. The results of the training activities conducted are very positively responded because it is closely related to their daily activities, so that felt is a major requirement. After implementing community service in the form of training, the joint venture groups have been successfully motivated entrepreneurship so as to be able to prepare a business plan, forming the organizational structure of the business group together, making a simple product packaging design.
\end{abstract}

Keywords:IbM, Joint Business Group 


\section{PENDAHULUAN}

Sektor Usaha Mikro, Kecil, dan Menengah (UMKM), telah memberi kontribusi 53 persen dari Produk Domestik Bruto (PDB) Indonesia pada tahun 2015, angka tersebut sangat signifikan, sehingga wajar bila sektor UMKM disebut-sebut sangat penting peranannya dalam menggerakan perekonomian nasional (Survei Ekonomi OECD Indonesia Maret Tahun 2015). Menurut Setia Iriyanto, Eny Winaryati, dan Siti Aminah, (2016), Saat ini populasi UMKM nasional mencapai 51,26 juta unit usaha atau 99 persen dari seluruh unit usaha yang ada di tanah air, maka berarti yang menggerakkan ekonomi bangsa ini adalah Sektor UMKM, bahkan sektor usaha ini yang telah menyelamatkan bangsa, terbukti ketika krisis moneter 1998, dimana sektor UMKM-lah yang bertahan dan relatif berjalan stabil.

Bidang-bidang usaha UMKM sangat beragam, seperti makananminuman, jasa, pertanian, perikanan, kerajinan, retail, transportasi, dan lain sebagainya. Di Desa Karondoran Kecamatan Langowan Timur Kabupaten Minahasa Suawesi Utara terdapat beberapa usaha rumah tangga/home industry kue tradisional yang dalam bahasa setempat disebut dengan nama kue kering "Bepang atan sebutan penduduk setempat adalah Rencina serta Kue Tradisional lainnya" yang bersifat kue kering dan tahan lama. Usaha rumah tangga ini tergolong masih bersifat sendiri-sendiri, sementarai itu dilakukan secara berkelompok dalam satu wadah yyang namanya Kelompok Usaha Bersama (KUBE), maka akan sangat bermanfaat baik karena akan lebih terorganisir.

Permasalahan yang dihadapi KUBE Home Industri kue kering "Bepang atau Rencina dan Kue Tradisional lainnya" ini khususnya produk utama yaitu "kue kering bepang-rencina", produknya masih berukuran besar, sehingga tidak menarik untuk dilihat maupun untuk memakannya. Secara umum sesuai hasil pengamatan bahwa produk kue kering ini belum ada sistem packing atau kemasan yang memenuhi standar pemasaran bermutu, sehingga produk cepat rusak, sering terbelah, karena pengemasan tidak baik. Selain itu ada hal lainnya yang tidak kalah menarik, yakni pelabelan produk kue kering ini belum menuliskan nama produk, tanpa adanya tanggal kedaluarsa, komposisi produk, keunggulan produk, nama yang membuat dan sebagainya. Sedangkan untuk produk yang sesuai standar BPOM dan Dinas Kesehatan, seharusnya setiap produk, wajib diberikan nama produk, komposisi produk, pemilik produk, tanggal kadaluarsa, dan lainnya.

Permasalahan lainnya bahwa KUBE ini masih bersifat individu-individu dan belum terorganisir. Sehingga belum ada struktur organisasi yang jelas sehingga menimbulkan tumpang tindih dalam tugas dan tanggung jawabnya. Selain itu permasalahan serius lainnya yang dihadapi adalah pemasaran produknya. Sekarang ini penjualan dilakukan hanya dengan menjajakan pada lapak-lapak kecil di pasar, sedangkan sisa produk yang belum terjual menunggu pembeli untuk datang di rumah produksi kue kering tersebut. Berbagai transaksi jual beli yang sebelumnya hanya bisa dilakukan dengan cara tatap muka, sementara itu terbuka kesempatan untuk menjual melalui telepon, dan bahkan kini sangat mudah dan sering dilakukan melalui Internet, seperti di akun facebook, twitter dan lainnya untuk promosi. Selain itu karena belum terbentuk pola kemitraan dengan Disperindag Kabupaten dan lainnya, mengakibatkan sistem pemasaran dan pengembangan produknya menjadi tidak terarah kearah baik.

Kerangka pemecahan masalah dilakukan dengan proses sebagai berikut: 1) Kondisi awal. Sebelum pelaksanaan kegiatan pelatihan tata kelola usaha, kondisi awalnya keadaan usaha kecil yang belum menerapkan sistem tata kelola organisasi, system pengemasan, tata kelola 
pemasaran produk dan tata kelola keuangan yang belum transparan dan akuntabel, disebabkan mereka belum tau dan tidak biasa melakukannya. Kodisi tersebut menyebabkan mereka tidak bisa mengelola usaha dengan baik dan terorganisir, kurang mampu menentukan dengan tepat sistem penjualan dan sistem pengelolaan keuangan yang belum efisien dan efektif. 2) Sentuhan ipteks melalui pelatihan. Metode pemecahan terhadap masalah yang dihadapi sistem tata kelola usaha, adalah melalui proses pelatihan. Dengan menggunakan metode pelatihan yang tepat tentang tata kelola organisasi dan tata kelola usaha dan pemasaran, serta cara-cara sistem pengelolaan keuangan yang efisien dan efektif, maka diharapkan akan terjadi perubahan perilaku. Tahap selanjutnya dilakukan tata kelola organisasi dan tata kelola usaha, serta pelaporan keuangan yang transparan dan akuntabel sebagai bagian dari pelatihan, sebagai aplikasi atas pelatihan yang dilakukan. 3) Hasil yang diharapkan. Sesudah pelaksanaan pelatihan disertai praktik pengorganisasian kelompok, sistem pengemasan produk, sistem pemasaran yang uptudate, serta sistem pengelolaan keuangan yang belum efisien dan efektif dan pelaporan keuangan yang transparan dan akuntabel, maka diharapkan akan terjadi perubahan perilaku.

\section{METODE IPTEKS}

Melalui kegiatan IbM ini akan ditawarkan solusi bagi permasalahanpermasalahan yang telah dirumuskan di atas. Pendekatan yang ditawarkan bagi realisasi program IbM ini adalah model pemberdayaan dengan langkah-langkah sebagai berikut : 1) Tahap Persiapan; 2) Tahap Assesment; 3) Tahap Perencanaan Alternatif Program atau Kegiatan; 4) Tahap Pemformulasian Rencana Aksi; 5) Tahap Pelaksanaan (Implementasi)
Program atau Kegiatan; 6) Tahap Evaluasi; serta 7) Tahap diseminasi.

Pelaksanaan program IbM ini dilaksanakan sebagai upaya pemberdayaan kelompok KUBE dalam bidang kewirausahaan dan pemasaran produk melalui kegiatan pelatihan yang menitikberatkan kepada pengembangan usaha dan pemasaran. Metode pelaksanaan program yang akan dilakukan adalah : (1) pelatihan manajemen usaha, (2) Pelatihan pemasaran usaha, (3) dan (4) pendampingan. Semua metode ini merupakan satu kesatuan dari program IbM ini.

Kegiatan pelatihan dilakukan dengan metode ceramah, metode tanya jawab, dan metode demonstrasi, diakhiri dengan praktek lapangan. Metode ini digunakan untuk menyampaikan materi kegiatan, setelah materi disampaikan dilanjutkan dengan metode diskusi antara sesama peserta diklat. Metode diklat yang dimaksud adalah keseluruhan cara dan teknik penyampaian. Materi dalam proses belajar mengajar yang antara lain berbentuk: 1). Ceramah dan diskusi; 2). Praktek; 3). Studi Kasus; 4). Simulasi.

Khalayak sasaran yang strategis dalam kegiatan ini adalah masyarakat Kelompok Usaha Bersama (KUBE) yang tergolong dalam Bentuk usaha kue bepang (rencina) dan kue basah lainnya yang berada di Desa Krondoran Kecamatan Langowan Timur Kabupaten Minahasa. Jumlah peserta pelatihan sebanyak 20 orang, dengan rincian sebagai berikut: Usaha Kue Bepang = 6 Orang; Usaha Kue kering Lainnya $=8$ Orang; dan Perangkat Desa/Tokoh Masyarakat $=6$ Orang.

\section{PELAKSANAAN KEGIATAN}

Pelaksanaan semua proses kegiatan ini dilakukan selama 3 bulan, mulai bulan maret 2017 sampai dengan bulan Mei 2017. Kegiatan meliputi: persiapan penyusunan proposal, pengajuan proposal, pelaksanaan kegiatan di lapangan sampai pelaporan kegiatan pelatihan. Khusus 
pelaksanaan kegiatan di lapangan di lakukan selama 5 (lima) hari, yang terdiri atas: survei awal dan observasi 2 (dua) hari, pelaksanaan kegiatan di lapangan 2 (dua) hari, yakni tanggal 24 dan 25 Juni 2017, yakni menyiapkan dan melaksanakan pelatihan dengan materi: penyusunan rencana usaha dan motivasi berwirausaha, pembuatan desain kemasan, manajemen dan struktur organisasi, dan strategi pemasaran, serta praktik di lapangan 1 (satu) hari, yakni tanggal 26 Juni 2017.

Hasil pengamatan selama pelaksanaan kegiatan yang ditunjang dengan hasil evaluasi atas pelaksanaan kegiatan pelatihan terhadap khalayak sasaran yakni peserta kelompok usaha bersama ekonomi kerakyatan, dalam hal ini adalah pembuat kue kering, serta tokoh masyarakat dan perangkat desa yang berkeinginan untuk ikut kegiatanyang ada di Desa Karondoran Kecamatan Langowan Timur, diperoleh beberapa hasl pokok, antara lain bahwa peserta memiliki keinginan kuat untuk memperoleh baik secara teoritis maupun parktik hal-hal yang berhubungan dengan kegiatan-kegiatan yang sangat dibutuhkan itu. Kegiatankegiatan yang dilakukan memang sangat menunjang para kelompok usaha kecil serta pemerintah desa dalam pelatihan ini sehingga kedepan menjadi pengusahapengusaha sukses di desa sehingga usahanya menjadi lebih teratur dan selalu terencana dalam pelaksanaan kegiatan sesuai dengan yang diinginkan oleh pemerintah.

Walaupun beberapa diantara peserta yang hadir sibuk melakukan usahanya sehari-hari, namun antusiasme para peserta pelatihan sangat tinggi karena dari hasil evaluasi awal maupun proses, ternyata para khalayak sasaran banyak yang belum mengetahui cara menyusun rencana usaha dengan benar serta cara memasarkan barang melalui media social dalam hal ini facebook, WA dan telepon, serta cara mendesain kemasan produk secara sederhana untuk produk kue kering agar menari bagi pembeli.

Materi yang dianggap paling mendapat perhatian adalah cara memasarkan barang melalui media social dalam hal ini facebook, WA dan telepon, melalukan kerjasama dengan pedagang eceran (warung, minimarket, dan lainnya), serta cara mendisaian kemasan produk secara sederhana untuk produk kue kering agar menari bagi pembeli. Bagi mereka ini adalah hal baru namun patut dicoba, apalagi materinya disajikan langsung didiskusikan sehingga menarik bagi mereka.Responsif mereka dapat dilihat dari hasil kerja praktik dalam bentuk membuat disaian produk yang dibuat oleh mereka walaupun masih banyak yang masih perlu diperbaiki, namun bagi mereka ini adalah langkah awal untuk melakukkan perobahan mendasar di usaha mereka.

Oleh karena itu setelah dilakukan praktik terhadap materi tersebut, antusiasme peserta sangat tinggi. Ini ditunjukkan oleh banyak diantara para peserta berupaya menyusun dengan bantuan dan bimbingan penyaji dan pembimbing praktik dan setiap saat ingin bertanya tentang cara-cara merencanakan usaha, cara memasarkan barang melalui media online, serta cara mendisain kemasan produk. Demikian juga halnya dengan praktik materi rencana kelayakan usaha (businness Plan), yang paling banyak bertanya adalah bagaimana menghitung rencana laba serta sistem pasar, sistem produk, serta strategi menetapkan harga jual yang pas tapi menguntungkan. Memang sangat disadari bahwa di desa yang mayoritas tingkat pendidikan yang kurang, menunjukkan bahwa kegiatan-kegiatan seperti ini jarang terjadi.Sementara itu mereka mengalami kesulitan dalam memahami cara-cara pembuatan dan pelaksanaan kegiatan. Untuk itulah kegiatan pelatihan yang berhubungan dengan materi tersebut merupakan kebutuhan yang tidak dapat 
ditawar-tawar, sehingga sangat direspons oleh para peserta sebagai pemilik usaha kecil dan pemerintah desa serta tokoh masyarakat desa.

Dari pelaksanaan kegiatan pengabdian kepada masyarakat tentang pelatihan kelompok usaha bersama (KUBE) kue bepang-rencina dan kue khas lainnya bagi Kelompok Usaha Kecil Di Desa Karondoran Kecamatan Langowan Timur, diperoleh hasil sebagai berikut:

- Penyusunan Rencana Usaha Dan Motivasi Berwirausaha

- Struktur Organisasi kelompok usaha bersama. Struktur organisasi KUBE yang terbentuk adalah sebagai berikut: Ketua, Wakil Ketua bidang pemasaran produk dan pengelolaan internet, Wakil Ketua bidang pengemasan/disain produk, Wakil Ketua bidang keuangan dan pembukuan, Sekretaris, serta anggota.

- Strategi Pemasaran dan Pembuatan Desain Kemasan produk kue kering yang sederhana melalui facebook, dan mengadakan hubungan dengan toko-toko oleole, serta super market di Langowan, Kawangkoan, dan di Manado.

- Contoh studi kelayakan usaha (businness Plan) yang sederhana.

Persoalan utama setelah kegiatan pelatihan ini selesai, yakni bantuan pendamping pada saat proses perubahan dari usaha-usaha tradisional ke usaha berorientasi modern, antara lain, sistem penyusunan berikut serta bagaimana mempraktikannya. Proses ini dilakukan dengan berkonsultasi melalui dinas terkait, seperti: pemerintah Kabupaten Minahasa atau perguruan tinggi yang memiliki kompeten membantu desa.

\section{KESIMPULAN DAN SARAN}

Berdasarkan kajian atas kegiatan pengabdian yang dilakukan pada kelompok usaha bersama kue kering di
Desa Karondoran Kecamatan Langowan Timur ini, maka berdasarkan hasil evaluasi, memperoleh hasil bahwa kegiatan ini sangat diperlukan oleh para pengusaha kecil termasuk pemerintah dan tokoh masyarakat desa setempat, karena memang sangat berkaitan dengan kebutuhan dan kewajiban pengelola usaha kecil. Atas dasar itu beberapa kesimpulan atas hasil kegiatan ini sebagai berikut:

1. Penyusunan rencana usaha dan motivasi berwirausaha merupakan materi penting yang bukan hanya diketahui, tapi patut dipahami dalam melakukan penyusunan kegiatan sebelum melakukan usaha. Temuan yang diperoleh ternyata para pengusaha kue kering ini tidak melakukan perencanaan usana secara cermat dan tertulis, melainkan hanya melakukan rencana usaha berdasarkan perkiraan sesuai pengalaman saja, sehingga sering terjadi hasil yang didapatkan meleset dari apa yang diperkirakan. Solusinya dilatih contoh perencanaan usaha.

2. Struktur Organisasi kelompok usaha bersama tidak ada, sehingga materi ini juga merupakan materi penting yang wajib diterima oleh para pengusaha kecil di Desa Karondoran Kecamatan Langowan Timur. Selama ini sistem pelaksanaan manajerial dan organisasi kelompok, hanya didasarkan pada inisiatif saja, sehingga kegiatan manajerial dijalankan secara tidak maksimal. Solusinya telah dibuat struktur organisasi Kelompok Usaha Bersama beserta tugas masing-masing.

3. Strategi pemasaran produk kue kering yang dijalankan di kelompok usaha bersama yang ada di Desa Karondoran Kecamatan Langowan Timur, cenderung dilakukan hanya menunggu pesanan saja, sehingga produk yang dihasilkan sering tidak terjual semua. Pemasaran melalui jaringan usaha melalui FB, WA, dan lainnya dianggap sangat penting sebagai saluran 
pemasaran produk mereka. Hal lain yang kurang diperhatikan adalah pembuatan desain kemasan produk kue kering yang dijalankan di kelompok usaha bersama yang ada di Desa Karondoran Kecamatan Langowan Timur, yang masih sangat tradisionil dan kurang manarik. Sementara disain produk yang menarik tapi sederhana sangat perlu untuk membuat agar produk menarik untuk dibeli konsumen. Solusinya dilatih telah dilatih tentang cara memasarkan barang melalui jaringan FB dan WA.

4. Setelah melaksanakan pengabdian kepada masyarakat dalam bentuk pelatihan, maka para kelompok usaha bersama besertatokoh masyarakat di Desa Langowan Kecamatan Langowan Timur telah berhasil memperoleh pengetahuan tentang penyusunan rencana usaha dan motivasi berwirausaha, struktur organisasi kelompok usaha bersama, serta desain kemasan produk kue kering yang sederhana, walaupun masih pada taraf yang sederhana,namun telah dapat membuka wawasan mereka tentang pentingnya ketiga materi ini.

Atas dasar beberapa kesimpulan yang telah dinyatakan tersebut, maka beberapa saran atas kegiatan ini adalah sebagai berikut:

1. Kegiatan pelatihan ini merupakan langkah awal bagi para kelompok usaha bersama besertatokoh masyarakat desa, sehingga perlu adanya pemantauan dan bimbingan teknik secara khusus baik oleh instansi terkait, maupun pihak perguruan tinggi; dengan demikian kegiatan semacam ini sangat penting dilakukan oleh Lembaga Pengabdian Kepada Masyarakat Universitas Negeri Manado dalam melaksanakan tugas Tridharma Perguruan Tinggi.
2. Penyusunan rencana usaha dan motivasi berwirausaha, struktur organisasi kelompok usaha bersama, serta desain kemasan produk kue kering yang sederhana akan sangat membantu para kelompok usaha bersama besertatokoh masyarakat desa dalam melaksanakan tugas utama mereka. Oleh karena itu pelatihan dan pembiasaan para pengusaha kecil dan tokoh masyarakat desa secara terus menerus yang diikuti dengan perobahan-perobahan sesuai perkembangan usaha, akan sangat sangat dibutuhkan. Paling sedikit setahun sekali dilakukan pelatihan berkaitan dengan materi seperti yang dilatih sekarang ini wajib dilakukan. Oleh karena itu tanggung jawab pemerintah kabupaten maupun perguruan tinggi seperti Unima merupakan harapan pemerintah desa.

\section{DAFTAR PUSTAKA}

Setia Iriyanto, Eny Winaryati, dan Siti Aminah, (2016), Ipteks Bagi Masyarakat ( IbM ) Home Industri Nata De Coco ( Sari Kelapa), USTRI NATA DE COCO ( SARI KELAPA) - Neliti, https://media.neliti.com/media/publ ications/22766-ID-ipteks-bagimasyarakat-ibm-home-industrinata-de-coco.

Survei Ekonomi OECD Indonesia Maret Tahun 2015, OECD Economic Surveys: Indonesia 2015, Étude économiques de l'OCDE : Indonesie 2015. (C) 2015 OECD. All rights reserved. 